\title{
Apuntes sobre el tema de la identidad cultural en la Región de Tarapacá ${ }^{1}$
}

\section{RESUMEN}

Este trabajo, redactado bajo la forma de un ensayo, recoge algunos de los componentes que el autor considera relevantes para abordar y problematizar el tema de la identidad cultural en la región deTarapacá. En primer término, se trata la relación entre identidad, historia y nacionalismo, enfatizando la manera en que la constitución de la nacionalidad chilena en un espacio de ocupación expulsa del imaginario cultural el período peruano y, además, por medio de políticas públicas abiertas o no declaradas, desde el Estado se imponen aquellos elementos culturales que, provenientes de la zona centro sur del país, se consideran representativos del deber ser nacional. En segundo lugar, se abordan algunas identidades de grupos particulares o ciertos componentes que todavía parecen influir en la definición de la identidad regional, además de otros que han aparecido más recientemente producto de los procesos de globalización de la cultura y la economía que afectan también a la región. Por último, a manera de conclusión, se tratan algunos elementos que, pese a su importancia pasada, están siendo o han sido relegados al abandono como constituyentes de identidad.

\section{ABSTRACT}

This paper, drafted under the form of an essay, gathers some of the elements that the author considers relevant in approaching the research problem of the cultural identity issue in the Tarapacá

1 Parte de las reflexiones sobre las que se basa este trabajo forman parte de actividades desarrolladas en el enarco de los Proyectos FONDECYT N 1960044 y 1970644.

2 Antropólogo, Depto. de Arqueología y Museología de la Universidad de Tarapacá. region. The relationship between identity, history and nationalism is treated firstly, emphasizing the way in which the constitution of the Chilean nationality, from its occupation space, expels the cultural imaginary of the Peruvian period; and further more, cultural elements originated in the south central region of the country are imposed as genuine national representative symbols by means of public and not declared politics. Secondly, some identities of particular groups are considered, or some elements that still seem to influence the definition of regional identity with others that have emerged more recently, as a product of the globalization process of culture and economy that also affects the region. Finally and as a conclusion, some other important elements are referred to, even though they have been relegated to a second place and abandoned as constituent of identity.

\section{Introducción}

La noción de identidad cultural supone la operación de dos principios: el de semejanza y el de diferencia. El primero rescata un sentido de participación: ser lo mismo que otros; el segundo uno de especificidad: ser distinto de otros. Aunque el acento en uno $u$ otro aspecto puede dar lugar a desarrollos teóricos y analíticos diferentes, ambos principios, en todo caso, deben referirse a contenidos y señales de distintividad.

El tema de la identidad o distintividad cultural de una determinada región se puede encarar por dos vías. $\mathrm{La}$ primera tiene que ver con el modo como configuran sus identidades los distintos grupos sociales existentes dentro del territorio regional. La segunda con la manera en que ciertos elementos, que pueden provenir de identidades grupales particulares, de síntesis y reelaboraciones locales o, incluso, de préstamos e influencias externas, son realzados -o despreciados- como constituyentes del imaginario colectivo de pertenencia y especificidad de los habitantes de ese espacio. Este trabajo transita entre ambas perspectivas. En algunos casos tratamos cier- 
tos elementos y en otros, especialmente cuando se podía situar mejor el origen, continuidad o posición de ciertos componentes, desarrollamos algo más algunas identidades grupales particulares.

De manera arbitraria se ha delimitado el espacio de reflexión a la actual Región de Tarapacá, lo cual constituye una decisión problemática, ya que en nuestro país las regiones son constructos políticoadministrativos arbitrarios, que no necesariamente se corresponden con áreas culturales. Esta situación explica el hecho de que algunos de los componentes que se destacan en este trabajo no necesariamente tengan un alcance regional, sino más reducido; y que otros, en cambio, excedan la región, al formar parte de sistemas de extensión territorial más amplia.

Los límites de la región de Tarapacá alojan tres realidades: sus dos ciudades costeras y la zona rural interior. Se trata de áreas que tienen distinta composición poblacional y distintos recorridos históricos. La realidad cultural de las urbes de la costa, que son las más importantes en términos demográficos ${ }^{3}$, es diferente a la del sector rural, compuesto mayoritariamente por población de origen aymara. A su vez, Iquique y Arica presentan componentes culturales particulares $\mathrm{e}$, incluso, una enemistad bastante enraizada.

Por otra parte, existen ciertos componentes culturales que exceden los límites territoriales regionales. Esta situación está relacionada, por un lado, con la existencia de un espacio cultural y geográfico más amplio: el Norte Grande; y, por otro, con la amalga-

3 En conjunto, ambas ciudades concentran actualmente el $92 \%$ de la población total regional.

4 Existe una gran cantidad de artículos y libros dedicados a la prehistoria regional. Síntesis de divulgación más amplia por períodos se pueden encontrar en: L. Núñez (1989) para el arcaico temprano; C. Santoro (1989) y A. Llagostera (1989) para los cazadore-recolectores de la puna y la costa, respectivamente; L. Núñez (1974 y 1989a) para la producción de alimentos y sedentarización; I. Muñoz (1989) para el formativo; J. Berenguer y P. Dauelsberg (1989) para la influencia tiwanaku en el área; y V. Schiapacasse et al. (1989) para las culturas de desarrollo regional.

5 Lo mismo que la labor de los primeros arqueólogos que se transformaron en conocidos personajes locales (como Percy Dauelsberg y Guillermo Focacci en Arica y Jorge Checura en Iquique, por nombrar a los más conocidos) y, aún autodidactas, en fundadores de la arqueología chilena. ma cultural que se da en una región que se ha formado por la confluencia de variados aportes migratorios provenientes del resto del país e, incluso, el extranjero.

Este trabajo fue elaborado bajo la forma de un ensayo. Como tal, en este caso, constituye un ejercicio de asociación de ideas sobre aquellos componentes que considero más relevantes en la constitución de la identidad e imaginarios culturales en la región de Tarapacá. Debido a mi formación profesional y mi campo de especialidad, es probable que trate desigualmente algunos temas o que, incluso, haya olvidado algunos que seguramente podrían ser de interés vistos desde otras disciplinas.

Por último, una cuestión de método. Aparte de las referencias bibliográficas obligadas y mi propio conocimiento sobre algunos temas, también sostuve conversaciones informales con colegas y amigos, con el objeto de obtener su opinión acerca de los elementos culturales que estimaban más importantes en términos de la configuración de la identidad regional y sobre sus características, origen y evolución. Aunque no estoy seguro de haber interpretado correctamente sus aportes y apreciaciones, es un deber agradecer su deferencia.

\section{Identidad cultural, historia y nacionalidad}

\section{El recurso a una historia discontinua}

La memoria histórica, aprendida por conductos formales o informales, constituye la reserva patrimonial de la identidad cultural para un grupo o un pueblo. Cualquier habitante de nuestro país puede espigar entre distintos períodos de su historia y retomar algún elemento que refuerce su identidad con la realidad local a la que pertenece: mayor o menor antigüedad del poblamiento prehistórico, el valor e indocilidad mapuche, las obras de tal gobernador, de la iglesia, la participación en la independencia, un héroe, algún gobierno, un político, una calamidad, una etapa de auge o crisis económica, etc. ¿Los habitantes de la región de Tarapacá pueden hacer un recorrido continuo por toda la historia de su territorio, por todos sus períodos, por todos sus años?

El período prehistórico está bien documentado ${ }^{4}$. A ello han contribuido tanto las especiales condiciones ambientales del desierto, que permiten una extraordinaria conservación de los restos arqueológicos, como la actividad de los propios especialistas, desde antes, incluso, que se iniciara profesionalmente esta ciencia en el país ${ }^{5}$. Las colecciones arqueológi- 
cas mostradas en las salas de exhibición o conservadas en las bodegas de los museos regionales, son un archivo de importancia nacional e internacional; pero, ademas, los anzuelos de concha, las balsas de lobos marinos, las momias Chinchorro, el arte rupestre, etc., son elementos de distintividad conocidos y valorados por los habitantes de la región ${ }^{6}$.

El período colonial es menos conocido, aunque la situación varía según el área que se trate. En lquique, donde su evocación parece ser menos importante que para Arica, la memoria se reduce al vago reconocimiento de la importancia de PicaMatilla y Tarapacá y la de ciertos personajes hispanos, criollos y mestizos que combinaron sus actividades agrícolas con la minería de hallazgo, especialmente en Huantajaya ${ }^{7}$. El olvido está relacionado con el traslado tardío de la dinámica pohlacional y económica desde los valles y oasis (el antiguo espa-

6 Iquique cuenta con un Museo Regional que funciona al alero de la Corporación Municipal de Desarrollo Social. Arica con el Museo Arqueológico San Miguel de Azapa, que depende del Departamento de Arqueología y Museología de la Universidad de Tarapacá, donde trabaja un importante grupo de investigadores y edita la revista Chungará.

7 La importancia del área de Tarapacá y la relación entre agricultura y minería de hallazgo está muy bien documentada en Sergio Villalobos (1979); se puede consultar también el trabajo de Oscar Bermúdez (1987) que, aunque centrado en Pica-Matilla, aborda sus nexos regionales.

8 Véase P. Advis (1994), B. Guerrero (1996) y S. González (1995b).

9 V. Dagnino (1909), A.Wormald (1968, 1969 y 1972) y L. Urzúa (1969), están dedicados en gran parte a Arica colonial, a su esplendor y ocaso. Curiosamente, las obras de estos historiadores fueron más conocidas en el ámbito local que la de los especialistas con formación universitaria que los reemplazarán, cuyos trabajos tendrán un ámbito de difusión más académica. En este último caso se encuentran Sergio Villalobos (op. cit), lorge Hidalgo (1986, entre varios de sus trabajos) y otros. Más desconocidos aún son textos referidos al área pero realizados por investigadores peruanos, como el de Efraín Tréllez (1983).

10 El fenómeno de la educación chilenizante está mejor documentado para el grupo aymara que habitaba los espacios interiores (cf. Sergio González, 1990 y 1996; para la labor de las preceptoras chilenizadoras y peruanistas véase, del mismo, 1997). cio de Tarapacá) a Iquique, en la costa: la colonia no parece tener importancia fundante para una ciudad que, en ese período, seguía siendo apenas una caleta de pescadores ${ }^{8}$.

En Arica, en cambio, la memoria colonial parece más fuerte, al menos en la ciudad del mismo nombre, que fue la capital del primer correjimiento en la región y vivió una época temprana de esplendor, entre fines del S. XVI y finales del S. XVII, cuando sirvió de puerto de entrada y salida para el mineral de Potosí. Después de este período, vivirá un ciclo de depresión económica y demográfica que se prolonga, incluso, hasta mediados del S.XX. Los historiadores locales y los propios habitantes de Arica rememoran constantemente su importancia colonial, rescatando incluso su escudo y decreto real de fundación 9 .

Este juego de olvido y evocación del pasado colonial trae a cuento la ciclicidad de la historia de la dinámica económica regional, un fenómeno que se proyecta también hacia otros componentes del imaginario cultural: si Iquique es una caleta sin pasado colonial vistoso, que se transforma en puerto recién a mediados del siglo pasado y con el auge del salitre; Arica es un puerto del pasado que se transforma en caleta después de la declinación del mineral argentífero de Potosí.

Si la etapa colonial regional es poco conocida o desigualmente aprehendida, según se trate de Iquique o Arica, el período republicano temprano, desde la Independencia hasta la Guerra del Pacífico es completamente ignorado. La historia regional da un salto sobre el periodo peruano, para recomenzar solamente desde la ocupación chilena de este territorio a fines del diecinueve.

Esta situación se relaciona evidentemente con las características que asume la incorporación de un territorio tras una guerra. La ocupación y la afirmación de soberanía por parte de Chile, supone la instalación de la nueva nacionalidad y la necesidad de borrar todo vestigio de la precedente. Aparte de politicas demográficas (traslado de población de otras partes del país y expulsión o facilidades para la partida voluntaria de ciudadanos peruanos), el estado chileno también aplicó prácticas culturales, basadas fundamentalmente en una política educacional centrada en el concepto de chilenidad ${ }^{10}$, especialmente a partir de la primera década de este siglo, cuando se avecindaba el plebiscito que debía zanjar la adscripción de Arica y Tacna a uno de los dos países involucrados.

El silencio sobre el período peruano señala una 
discontinuidad para la internalización de la historia regional. Reconocer un período prehispánico o colonial parece no ser tan doloroso como admitir que también existe un período de pertenencia a otra nacionalidad. Este velo se extiende también sobre el fenómeno de chilenización compulsiva y violenta que se desata entre 1910-1929 en las ciudades de Arica e lquique, con formación de ligas patrióticas que persiguen a los ciudadanos peruanos que todavía quedaban. Estos hechos, que todos pueden rastrear en la intimidad del recuerdo familiar, no son explicitados hacia la conciencia colectiva. Más aún, salvo recientes intentos, la propia historiografía local los ha ignorado ${ }^{11}$.

\section{Nacionalismo: militares, educación y huasos}

Un dato de la realidad: un habitante de la región sabe más de los hechos y batallas de la guerra, del heroismo y valentía del soldado chileno (y de los valores opuestos de los vencidos), que de las encomiendas y doctrinas coloniales, de la situación de los indígenas en ese momento y menos todavía de la historia republicana temprana regional, cuando este espacio era parte del sur del Perú.

Los tarapaqueños aprenden y conocen más de la historia de la Guerra del Pacífico y viven en un ambiente más militarista que cualquier ciudadano del país. Hoy por hoy, sólo en estas latitudes se celebran o recuerdan efemérides como el asalto y toma de Pisagua y del Morro de Arica, batallas como las de Tarapacá, Dolores u otras, junto a los mártires o héroes de ese conflicto. El 21 de mayo en Iquique no es sólo una acción recordatoria, sino un verdadero aniversario de identidad local. Es la rememoración de un evento constituyente, como el acto de fundación de la ciudad. Es también una evocación sacrificial

11 Con excepción de los trabajos de S. González, C. Maldonado y S. McGee (1993) y del mismo Sergio González (1995 y 1997a). Para una visión peruana de la chilenización de Tacna y Arica, véase R. Palacios (1974).

12 El servicio militar obligatorio figura entre unos de los principales elementos de asimilación para los indígenas del interior. Varios de ellos han pasado, incluso, de los sones de sus instrumentos de viento tradicionales a los bronces de las bandas militares.

13 Véase Sergio González (1996). que, desde la epopeya bélica, se inserta en un largo historial de otros sacrificios en la historia social de la región, como el de los obreros durante el ciclo salitrero o de los fusilados en Pisagua en 1973.

Tampoco hay que olvidar la influencia que proyectan sobre la conciencia y la vida regional la gran cantidad de regimientos y contingente militar presente en esta zona fronteriza como la de Tarapacá. Las bandas paramilitares de cada rama de las fuerzas armadas, en las cuales participaron muchos iquiqueños y ariqueños hasta hace algunas décadas, se han prolongado en los colegios. En la actualidad, tanto en Arica como en Iquique, cualquier establecimiento de enseñanza media que se precie, incluidos los particulares, cuenta con una banda de este tipo. Los desfiles dominicales de delegaciones de estudiantes, junto con las de otras organizaciones civiles de la ciudad, son un elemento constitutivo de las prácticas cotidianas de sus habitantes. La disciplina del desfile entronca también con las organizadas marchas obreras. En el sector rural, en tanto, los alcaldes, carabineros o los destacamentos militares de las comunas interiores proyectan la misma situación hacia los niños aymaras ${ }^{12}$.

Dentro de esta lógica de constitución de la nacionalidad en un nuevo espacio de ocupación, no sólo destacan los elementos militaristas. También son importantes la visión y percepción de lo indígena -cuestión que trataremos más abajo-, las políticas explícitas o implícitas de la educación formal y la proyección de la imagen de Chile central como un estereotipo de ser nacional.

No se trata sólo de la presencia militar en sí. La rememoración de efemérides bélicas, los desfiles dominicales, así como la internalización de otros aspectos destinados a realzar la chilenidad, fueron asumidos tempranamente como política educacional. La introducción de la escuela se da muy temprano, no sólo en la costa, sino también en la pampa, coincidiendo con el afán ilustracionista del obrero salitrero, que la incorpora a sus demandas. Cerradas las salitreras, hacia los años treinta, la expansión de la educacional formal se mueve hacia el interior, hacia las comunidades de origen aymara. Pero no es sólo la escuela y el profesor, sino sus contenidos de chilenidad. En las escuelas normales, incluso, se llegaron a formar docentes "chilenizadores"13. Estos aires de la educación se exacerbaron durante el régimen militar, el que los asumió como una cuestión de geopolítica, especialmente en el sector rural. Actualmente, aunque más desdibujados, todavía se mantienen. 
La educación chilenizante no tiene que ver solamente con su aspecto militarista, sino también con la proyección de la imagen campestre de Chile central que el país ha adoptado como símbolo del ser nacional. Nada más extraño que ramadas, cuecas y huasos sobre un fondo desértico. Sin embargo, no hay fiesta dieciochera ni magisterio, personal municipal o de empresas que se les resista. Los periodistas de ambas ciudades, con más énfasis que en el resto del país, cada año reclaman por la música de las fondas, por el poco respeto por la cueca, nuestro baile patrio. En Arica existe un club de huasos y se celebra todos los años el campeonato ¡nacional! de cueca. Son, sin duda, imágenes de campo de la zona centro sur de nuestro país en el desierto, precisamente donde existe un rico reservorio de música andina y la mayoría de los agricultores son aymara; una elección de sentido para el ser o el deber ser chileno.

\section{Identidades tradicionales: elementos de continuidad}

\section{El componente indígena}

El componente indígena tiene al menos tres aspectos que se pueden destacar. El primero se refiere a lo que el pueblo aymara representa en el imaginario de una región de frontera y ocupación; el segundo está relacionado con la propia identidad de este grupo; y el tercero con los elementos que, bajo la forma de sincretismos o reelaboraciones, la cultura indígena ha aportado a otros componentes de la identidad regional. Los dos primeros se tratan en esta sección, mientras que los últimos son mencionados, cuando corresponde, en otros apartados de este trabajo.

\section{* Los aymaras vistos desde la región}

A diferencia de lo que ocurre en países como México, en Chile la cultura indígena no es, definitivamente, un elemento fundante para la identidad nacional. En este contexto de desprecio general, sólo se rescata la valentía, independencia e indocilidad de los mapuches frente al conquistador español, aunque más tarde los mismos son reducidos al estereotipo

14 Véase H. González y V. Gavilán (1990), Van Kessel (1992) y González y Gundermann (1996).

15 Cf. H. Gundermann y H. González (1989). del indio flojo y borracho. El resto ha sido sencillamente ignorado.

En el caso de los aymaras, habitantes originales de este territorio, bajo la égida chilena y en un contexto de ocupación, su cultura pasa a ser el símbolo de la extranjeridad sometida y del atraso o barbarie (india) de los vencidos. Desde ese momento, cuando un aymara usa su ropa tradicional, desarrolla sus ritos o habla su lengua, no sólo es indio -estigmatizado también durante la colonia y luego como ciudadano del naciente Perú republicano-, sino también el estereotipo de los países vecinos. Ataviados de su cultura son la imagen de Titicaco del dibujante Pepo, el compañero de Condorito, que con su chullo, su poncho, sus ojotas y sus "puis", señala caricaturescainente la imagen que Chile tiene de Bolivia.

Esta proyección desvalorizadora de su cultura fue asumida tempranamente por los propios aymaras del sector rural y, luego, sufrida como discriminación por los migrantes que comenzaron a instalarse a partir de los años cincuenta de manera más masiva en las ciudades costeras. En el primer caso significó el desencadenamiento de procesos de pérdida cultural y aculturación por imposición e imitación; en el segundo, pero sólo a partir de los años ochenta, el surgimiento de un movimiento étnico, una consecuencia más feliz ${ }^{14}$.

\section{* Rasgos de la identidad cultural aymara en Chile}

En general, en concordancia con su conexión con los procesos históricos regionales, el mayor o menor grado de aculturación de los aymara varía según el piso ecológico y la latitud. El altiplano y la cordillera son afectados en fecha más tardía, pero existen diferencias entre los sectores que corresponden, aproximadamente, a los Altos de Iquique y Arica, pues en esta última área el proceso se desencadena con anterioridad. En los valles los cambios operaron mucho antes, primero en los más meridionales, por su cercanía a las salitreras, y luego en los septentrionales, influidos por el vertiginoso crecimiento urbano de Arica a partir de los cincuenta ${ }^{15}$.

Se calcula que actualmente nada más que un $40 \%$ de los aymara habla su lengua. Sólo en el altiplano existe una mayoría de aymara parlantes, pero entre las generaciones jóvenes el uso es cada vez menor. Paradójicamente, productos de los procesos migratorios que han determinado que la mayoría de los aymara residan actualmente en Arica e Iquique, 
el mayor número de hablantes se encuentra en estas ciudades, espacios de asedio lingüístico que aceleran su desuso ${ }^{16}$. Muchos de los rasgos culturales que se podrían considerar como "tradicionales" han desaparecido o están en proceso de transformación. Diversas concepciones sobre el mundo natural, aspectos de su sistema parental y herencia, de su organización política, etc., ya no son compartidos por todos los aymara chilenos.

Pese a lo anterior, continúan siendo un grupo que contrasta al interior de la región. Su cultura se ha transformado, pero todavía mantiene espacios que aseguran su reproducción y le permiten la vitalidad suficiente como para asegurarles especificidad, incluso en sitios tan adversos como la ciudad. Su cultura se ha modificado si se la compara con alguna matriz andina "original", pero sigue haciendo de ellos un grupo diferente y particular ${ }^{17}$. Tanto en el campo como en la ciudad, aparte de la marginalidad económica y social proveniente de su condición de campesinos o pobladores, continúan siendo aymaras.

En el sector rural los aymara se caracterizan por tener un tipo de identidad localista, un fenómeno que continúa incluso entre los migrantes urbanos ${ }^{18}$. La pequeña localidad rural (la comunidad o la aldea), es un espacio donde se siguen manifestando diversos mecanismos de cohesión e identidad cultural. Entre ellos se han destacado la mantención de ciertas

16 Véase los trabajos de Hans Gundermann (1994) y Sergio González (1990).

17 Una concepción holocáustica a partir de matrices culturales dadas una vez y para siempre se encuentra en Van Kessel (1992). Para una crítica al concepto de matriz cultural y los planteamientos "tiempo-centristas" del autor anterior, véase M. Arratia (1992), H. González y V. Gavilán (1990) y González (1997).

18 Para una descripción de este tipo de identidad localista véase H. González y V. Gavilán (1990). Para su continuidad urbana véase H. González (1996) y K. Tabilo et al. (1996).

19 Esta influencia abarca a las I y II regiones, que es donde tiene lugar físicamente el ciclo salitrero (para una definición del espacio que abarcó el enclave salitrero, véase S. González, 1991). Seguramente llega también más al sur, especialmente al Norte Chico, con el retorno de los trabajadores a sus lugares de origen. Se ha detectado incluso su influencia en el movimiento sindical agrícola de los valles cochabambinos de Bolivia (G. Rodríguez, 1987). características de su sistema parental que incide en la circulación de los recursos más vitales al interior de la localidad; aspectos religiosos y rituales relacionados con la advocación religiosa local (santos patronos), carnaval, celebración de los difuntos de la comunidad, etc.; la apropiación y manejo de recursos y de mano de obra comunitaria; mecanismos de convocatoria y funcionamiento de la organización colectiva local, entre otros.

Este tipo de identidad localista no parece dejar espacio a la formulación de una identidad étnica más amplia: más que aymara se es de un pueblo tal o cual. Sin embargo, con el paso a la ciudad, especialmente entre las generaciones jóvenes, precisamente en aquellos en quienes sus padres apostaban a la aculturación y ascenso vía la educación, a partir de los años ochenta se comienza a gestar un movimiento étnico que reclama una identidad global, que traspasa incluso las fronteras y los une con sus congéneres peruanos y bolivianos.

\section{Elementos pampinos}

El esplendor del ciclo salitrero terminó con la crisis de los años treinta, aunque se mantuvieran algunas oficinas funcionando hasta los setenta. Disuelto el grupo social que la sustentó, es lógico que se extinga su identidad cultural. Sin embargo, muchos elementos de la cultura pampina siguen todavía incidiendo en variados aspectos del imaginario cultural e, incluso, en algunos de los componentes más visibles de la identidad cultural regiona ${ }^{19}$. Los migrantes pampinos influirán también directamente en las ciudades de Iquique y Arica, aportando costumbres, ideales y valores a la convivencia con porteños e inmigrantes de fuera de la región.

Dentro del imaginario cultural regional, destaca la imagen de la pampa como el lugar de nacimiento del movimiento obrero, sea con la creación de las mancomunales, la militancia política en la Federación Obrera y el Partido Obrero Socialista o la participación organizada de la mujer. Se trata de un movimiento que no sólo condensa reivindicaciones estrictamente económicas (mejores condiciones laborales y salarios dignos), sino también culturales, muy relacionados con el fenómeno de la ilustración que caracterizó al movimiento obrero de la época: preceptores, sociedades de socorros mutuos, teatro, música y prensa obrera.

Aunque los pampinos participaron de un movimiento social laico por esencia e, incluso, las iglesias no formaron parte sino hasta mucho después del 
paisaje urbano de los campamentos, fueron también creyentes y devotos, efectuando una síntesis de las diferentes tradiciones de las que provenían sus distintos componentes poblacionales: indígenas, campesinos chilenos, peruanos, bolivianos, argentinos, europeos. El vínculo hombre-pampa también se fundó en un elemento mítico-religioso que perdura hasta hoy en el imaginario cultural, tanto en su relación con la naturaleza como con lo sobrenatural. La concepción de la pampa como proveedora y quitadora de vida todavía subsiste en el respeto a las animitas y circula en leyendas sobre aparecidos y

20 Quien mejor ha trabajado el fenómeno del ciclo salitrero desde una perspectiva cultural es Sergio González (1991). Respecto del tema del salitre en general, donde se ha privilegiado el tema económico y social, existe una enorme bibliografía, destacando los trabajos de O. Bermúdez (1963 y 1984) y H. Blakemore (1977), entre otros. Desde la novela, no se pueden dejar de mencionar los aportes de Andrés Sabella (1959) y, últimamente, de Hernán Rivera (1994). En términos de revitalización del fenómeno pampino, no sólo entre los ex-trabajadores de salitre, sino también en la conciencia regional, debe destacarse el trabajo del Taller de Estudios Regionales, con su Revista Camanchaca, dirigida por Sergio González y colaboradores, como Juan Vásquez, Luis Castro, Mario Solezzi y otros. Para una compilación de textos seleccionados aparecidos en esta revista véase J. Vásquez (1994); un glosario de voces pampinas en S. González (1992).

21 Para E. Devés (1994), "este sacrificio no alcanza su realización en una vida espiritual, mística, mediada por fenómenos sobrenaturales, sino que su realización se alcanza laicamente en la lección o el uso que los vivos puedan hacer de él".

22 El cosmopolitismo aportado por la confluencia de distintos aportes culturales, frente a la exageración de una singularización chauvinista, ha sido relevado por Sergio González (1995b).

23 Destaca en este tema Bernardo Guerrero (1996), que con la metáfora del chumbeque (la tradición representada por un dulce de la zona) y la Zofri (la modernidad) ha esbozado un panorama de la identidad cultural de Iquique, que ha tenido una amplia divulgación. El libro de L. Núñez (1996) sobre Freddy Taberna, un dirigente socialista asesinado por los militares en Pisagua en 1973, es también un elogio a El Morro, uno de los barrios más antiguos de Iquique. En Arica, lamentablemente, salvo algunas esporádicas crónicas de prensa, es más desconocida la situación de sus barrios más tradicionales. acontecimientos sobrenaturales. La celebración de carnavales en las oficinas y la formación de cofradías y bandas para asistir a La Tirana son fenómenos que se trasladan desde la pampa al puerto ${ }^{20}$.

La muerte, desde el accidente laboral hasta la masacre, es también un concepto sacrificial que transita hasta hoy en el imaginario cultural regional, para simbolizar la tragedia que acecha a los trabajadores, tanto en sus lugares de trabajo como cuando luchan por sus demandas ${ }^{21}$. Las animitas de las faenas y el mausoleo colectivo para los mártires forman parte de una concepción especial de la muerte, donde se amalgaman también distintas concepciones de lo sobrenatural.

Otro componente importante del ciclo salitrero y que parece persistir hasta hoy es la conceptualización de ciclos de crisis-prosperidad como parte del destino de pueblos y ciudades en el desierto y, por extensión, de sus habitantes. Aunque esta visión pueda tener raíces históricas más profundas (como el desplazamiento del centro gravitacional de la economía tarapaqueña desde los valles a Iquique en la costa o el paso cíe puerto a caleta de Arica), no se comparan con la imagen del cierre de oficinas salitreras, aún durante el período expansivo del ciclo salitrero, los traslados de una oficina a otra, de un oficio a otro $\mathrm{y}$, por último, la de los fantasmales poblados y cementerios abandonados de la pampa, que recuerdan al viajero la fugacidad o finitud del esplendor económico.

La pampa también aporta la imagen cosmopolita que siempre tendrá el cíclico desarrollo regional, basado siempre en una economía de exportación o en políticas estatales de excepción ${ }^{22}$ En el ciclo salitrero participaron no sólo chilenos que llegaron de otras regiones del país, sino también indígenas aymaras y quechuas, ciudadanos peruanos, bolivianos, argentinos, además de un variado contingente proveniente de Europa (ingleses, italianos, españoles, croatas, alemanes, etc.) y Asia (chinos). Desde sus respectivas culturas de origen, todos aportaron a ese verdadero crisol cultural que tuvo lugar en tiempos de la explotación del salitre.

\section{El barrio}

Uno de los aspectos más descuidados de la investigación social y cultural en la región es la importancia del barrio, especialmente de aquellos más antiguos de sus dos ciudades principales ${ }^{23}$. Por ejemplo, no basta ser de Iquique, siempre se debe especificar el barrio. Una vez identificado, el sujeto es plenamente 
percibido como original de un grupo de bravos o relativamente fieros pobladores, como buenos nadadores o futbolistas, como pescadores o migrantes pampinos, habitantes antiguos o recientes, pobres o de clase media, etc.

De manera parecida a la localidad para los aymaras, el barrio es, además de referente, un refugio. El lugar donde se nace, se vive al menos los períodos más significativos $\mathrm{y}$, con suerte, se muere. Un ámbito reducido donde son posibles las relaciones cara a cara, donde todos se conocen y es posible la solidaridad grupal a una escala alcanzable de reciprocidad. En el barrio está la casa propia y, seguramente, la de los familiares; el club deportivo; el baile religioso; las fuentes de soda; el reducto donde se está a salvo; donde se tienen los amigos y se practican los primeros escarceos amorosos.

El crecimiento urbano, vivido por Arica a partir de los años cincuenta y por Iquique desde los ochenta, provoca una revalorización de los cascos antiguos de estas ciudades, donde se ubican precisamente los barrios más tradicionales. Esta situación trae aparejado la desaparición o el debilitamiento del componente barrial como mecanismo identitario, ya que se produce una dispersión de sus residentes. De todas maneras, al menos en Iquique donde el fenómeno está mejor documentado, aun modernizados, con inmigrantes y emigrantes, los barrios siguen teniendo relativa vigencia. Aunque ya no se puede dar una convivencia diaria o ya no es posible continuar residiendo, existe el recurso de la reunión en el club deportivo, en el baile religioso o, si es necesario, la vieja esquina de encuentro y sociabilidad.

\section{El componente religiosidad popular}

La religiosidad popular es un fenómeno que ha sido destacado como uno de los principales componentes de la identidad cultural latinoamericana, especial-

24 Destacándose la obra de P. Morandé (1984).

25 Como las realizadas por J. Larraín (1996).

26 Sobre la fiesta de La Tirana en específico, existen varios trabajos, siendo los más importantes los de de J. Uribe (1970) y L. Núñez (1989b). Para el caso de la Virgen de Las Peñas se cuentan los textos de E. Vásquez (1990) y Van Kessel (1992). En general, para los bailes religiosos que asisten a los santuarios más importantes del Norte Grande se pueden destacar los trabajo del Van Kessel (1988) y P. Henríquez (1996). mente desde una perspectiva esencialista o de pertenencia ${ }^{24}$. Independientemente de las críticas que se puedan formular a estos planteamientos ${ }^{25}$, es un hecho que la religiosidad popular juega un importante papel en los imaginarios colectivos del área.

En la región tarapaqueña, aparte de otros aspectos (como la conceptualización de la muerte presente en el culto de animitas, relatos y leyendas, procesiones, etc.), los fenómenos más destacables de religiosidad popular son las festividades de santuarios de La Virgen de La Tirana en el área de Iquique y la Virgen del Rosario de Las Peñas en la zona de Arica. $\mathrm{Su}$ devoción se manifiesta no sólo en las multitudinarias peregrinaciones en los días dedicados a sus advocaciones, sino también en el resto del año en la vida cotidiana de los sujetos, en cuestiones como mandas, bailes y cofradías religiosas, el bailarín promesero, etc.; además de las conceptualizaciones subyacentes al culto que inciden en los imaginarios colectivos, con temas corno el mestizaje y el sincretismo, comunes al culto mariano latinoamericano.

La manda o la promesa, los actos de reciprocidad por el cual se agradece o se solicita un favor de la virgen del Carmen o de Las Peñas forma parte de la experiencia de una familia en la región, especialmente de las de los sectores populares. Este año, alguno pasado o por venir, siempre alguien conocido prende cirios, lleva camisetas o vestidos de color café o rojo, prende billetes, regala un manto o una joya, realiza una caminata, transita de rodillas o se arrastra desde el calvario al templo. Otros se convierten de por vida o por periodos, según la prometido, en alguno de los personajes y figuras de estas festividades. Como bailarín de alguno de los cientos de bailes religiosos que, todavía en estos tiempos de modernidad, llenan de música las calles de los barrios de las ciudades en los ensayos de los meses previos a las celebraciones. Como portador para sacar los santos o la virgen durante las multitudinarias procesiones. Como camareras encargadas de vestir y atender sus imágenes.

Las leyendas fundantes y las características del culto en ambos santuarios remiten a conceptualizaciones que se enmarcan dentro de la tradición mariana latinoamericana. Estas tienen que ver, principalmente, con el mestizaje: entre indios y conquistadores en el caso de La Tirana, entre mestizos y criollos en el caso de Las Peñas; y con el sincretismo religioso: la imagen de la virgen sobre una luna o grabada en la piedra, dos elementos de la tradición andina precolombina; o la paloma angelical y la serpiente indígena, representando el cristianismo hispano y el paganismo indígena, etc ${ }^{26}$. 


\section{La mujer: soledad, lucha y solidaridad}

Para abordar el tema de la mujer en la región seguramente serían de utilidad algunos conceptos que han sido planteados en el análisis de la especificidad de la identidad femenina latinoamericana ${ }^{27}$. Lamentablemente, a nivel regional existen muy pocos trabajos al respecto ${ }^{28}$. De todas maneras, me parece interesante destacar algunos elementos especiales, como el de mujer sola, luchadora y solidaria.

Los vaivenes de la economía regional y las características especiales de algunos de los sectores productivos más importantes otorgan un sustrato objetivo a la idealización cultural de la condición de la mujer sola, que se hace cargo del hogar y los hijos mientras el marido está ausente. Los ciclos de períodos de empleo y cesantía que afectan al espacio regional obligan al traslado de los hombres a otros

27 Tales como los de madre/esposa, ícono mariano, mestizaje y otros (véase S. Montecino, 1991).

28 Un intento en este sentido se encuentra en un número especial de la revista Temas Regionales, dedicado a "la mujer en la cultura y la sociedad del norte de Chile, una recopilación de trabajos que abarcan el período salitrero, con el testimonio de una militante comunista (S. González, 1995) y la visita de Belén de Sárraga a Iquique, su influencia y reacciones en la sociedad local (B. Guerrero, 1995); la mujer aymara, con una aproximación a la construcción de las relaciones de género en esa cultura en el norte de Chile (V. Gavilán, 1995) y las mismas en relatos orales (K. Tabilo, 1995): y la mujer en la ciudad de Arica, con una mirada a la participación femenina en el mercado de trabajo urbano (A. Carrasco, 1995) y sobre la constitución de la condición de mujer jefa de hogar en los sectores populares (H. González. 1995).

29 Desde el punto de vista de la definición cultural de las relaciones de género, sería interesante pesquisar hasta qué punto esta imagen se contrapone con la del hombre "lacho", con mujeres e hijos fuera del hogar, irresponsable pero soportable (para el Norte Chico, véase el trabajo de J. Pinto, 1996).

30 El ejemplo de las mujeres de luto que todos los 11 de septiembre, aún en los años más duros de la dictadura militar, reclamaban en las gradas de la entrada de la catedral de Arica es todo un símbolo.

31 Para el caso de la mujer en el período salitrero y la manera como es percibida por los movimientos obreros de la época, se puede consultar el trabajo de L. Castro (1994). puntos en busca de trabajo; la minería y la pesca artesanal e industrial son, a la vez, actividades que obligan al hombre a abandonar por períodos su familia. En los sectores populares, la imagen de la mujer sola, con marido que parte, se va o trabaja fuera, se asocia comúnmente con conceptos como los de valentía, sacrificio y esfuerzo ${ }^{29}$.

La mujer de la región de Tarapacá tiene un largo historial de lucha y participación social y política. Esta característica arranca desde la época del salitre, con su participación en mancomunales y en los centros femeninos ${ }^{30}$, continuando posteriormente en agrupaciones vinculadas a la FOCH y, luego, al $\mathrm{MEMCH}^{31}$. La asociación entre mujer, lucha y participación social continúa hasta hoy, a través de su fuerte presencia en comités de allegados y juntas vecinales, sorprendiendo su preparación y valentía.

La imagen de la mujer del campamento salitrero reaccionando contra la pulpería por el costo de los alimentos o colaborando a sostener la huelga con ollas comunes se ha prolongado en el tiempo. De esta manera, en el paro obrero o en las recurrentes situaciones de crisis que vive la economía regional durante este siglo y que afectan más duramente a las áreas urbanas marginales, siempre aparecen las mujeres donando o recolectando víveres, apoyando o cocinando para el colectivo afectado (el gremio, el sindicato, un comité de allegados o una agrupación vecinal). La solidaridad es, sin duda, un elemento constituyente de la identidad femenina en los sectores populares de la región.

En otro plano de la solidaridad colectiva femenina, es destacable que todavía perduren algunas sociedades de socorros mutuos de señoras, cuyos primeros antecedentes se encuentran en el período salitrero. Vinculado con este punto, otro elemento interesante de rescatar, pero muy poco atendido, es la relación entre mujer y ahorro familiar, que puede funcionar en términos de acumulación para provisión de gastos a realizar u obligación de reserva futura por contracción de deuda a plazo. Son ellas las que generalmente se encargan de juntar el dinero necesario para la vivienda social o de manejar las finanzas familiares para el endeudamiento planificado, sea con el almacenero o la tienda de la cadena comercial.

\section{Iquique tierra de campeones}

Como en otros puntos del país, las proezas de los héroes deportivos locales se transmiten de manera informal en las casas, en los barrios, los colegios, en polvorientas canchas, en pobres recintos deportivos 
o -en este caso- en las playas. Aunque Arica cuenta con algunos personajes que han sobrepasado el plano local, la mayor parte de sus prohombres y, por extensión, sus logros deportivos como ciudad, tienen un esplendor y resonancia más restringida. Iquique, en cambio, se sitúa como la "tierra de campeones", con estrellas en distintos ámbitos del deporte que alcanzaron fama nacional y que, incluso, han pasado a ser símbolos nacionales (como el Tani Loayza o Arturo Godoy), aunque, en realidad, hayan sido casi siempre "semi-campeones".

Curiosamente, el esplendor deportivo de Iquique coincide con la postración económica que vive la ciudad entre el inicio definitivo de la crisis del salitre a comienzos de los treinta y la instalación de la industria pesquera en los sesenta ${ }^{32}$. En un período en que la población local se redujo, abundaba la cesantía, los habitantes protestaban con banderas negras, se consiguieron los éxitos deportivos más resonantes que sustentan la imagen que todavía continúa de los iquiqueños campeones, en la que siguen solazándose sus habitantes y transmitiéndolas a sus hijos y al país.

Pero, detrás de la imagen del esplendor también se transmite una imagen de perseverancia y proeza. Precisamente cuando más pobres materialmente, más ricos deportivamente. Lo que se destaca, en el fondo, es el valor de vencer con recursos más escasos

en una situación más desfavorable que la de los contrincantes. El Tany peleó con un tobillo quebrado, Godoy soportó el castigo de un gigante, los equipos de fútbol más recordados son aquellos amateur o recién profesionalizados que derrotaron a Unión Española, el campeón nacional de 1943, o al Colo-Colo de estrellas en la final del torneo de apertura de 1980, en el mismísimo estadio nacional.

32 B. Guerrero (1992) es quien ha señalado esta paradoja en un texto donde, además, se reseñan las proezas y héroes deportivos de esta ciudad.

33 El año 1935, en Santiago, cuando se disputa por primera vez a nivel nacional y no por distribución de asociaciones (B. Guerrero, 1992).

34 Sobre las manifestaciones regionales de arte rupestre precolombino existen numerosos trabajos. Aparte de inventarios y relevamientos, se pueden citar: H. Niemeyer (1972), L. Núñez (1976 y 1985), G. Motsny y H. Niemeyer (1983), L. Briones (1984) y L. Briones y J. Chacama (1987), entre los más importantes.
Esta asociación entre pobreza y valor seguramente tiene sus raíces en la pampa, en la imagen de fortaleza del trabajador salitrero. De hecho, los deportes se practicaron intensamente en las oficinas y, de hecho, el primer equipo iquiqueño campeón nacional era, en realidad, la selección de la oficina San Enrique $^{33}$. Pampinos y costeros, conviviendo en el puerto, en un ambiente de depresión, volcaron sus energías en el deporte. La ciudad, pese a que ya no obtiene títulos como los de antaño, los sigue recordando. De esta manera, en cada club deportivo de barrio, junto a la figura nacional de moda, existe también un referente local.

\section{Arica, ciudad de la eterna primavera y la concep- tualización del entorno geográfico}

"Arica ciudad de la primavera", ¿slogan turístico o factor de identidad? Aunque es probable que tenga un origen promocional, lo cierto es que, de manera similar a "tierra de campeones" para los iquiqueños, esta frase es actualmente un signo de auto y exoreconocimiento para los ariqueños.

Después que Arica fue constantemente descrita como un puerto venido a menos, con una población diezmada por la malaria, se ofrece la primavera. ¿Por qué primavera y no verano? Aparte de la influencia mediterránea que efectivamente anula las oscilaciones térmicas diarias que se observa más adentro en la pampa, está también figurada la intención de temperar la imagen del hábitat, haciéndola menos radical e insufrible. Lo grato se encuentra lejos de los polos: del frío del invierno austral, serrano, altiplánico o de la noche pampina, pero también del verano caliente tropical o meridional y de la canícula del desierto. ¿Una oferta de clima temperado para hombres temperados?

Aparte de la importancia que la imagen tiene para el desarrollo económico de una ciudad postrada, creemos que ella también tiene que ver con la particular relación hombre-paisaje que desde tiempos inmemoriales puede rastrearse en los rituales, símbolos e íconos con que los diferentes grupos sociales han tratado de aprehender culturalmente su subsistencia y convivencia con un ambiente desértico como el que caracteriza la región.

Los antiguos geoglifos de los cerros, indicadores y descansos rituales para las antiguas caravanas que cruzaron el desierto ${ }^{34}$, todavía se encuentran para señalar el nombre de la localidad en los poblados del interior; a la vera de caminos para señalar el nombre de los viajeros, su procedencia o alguna declaración 
de amor; en la propaganda de candidatos y partidos políticos o credos religiosos en los imponentes cerros costeros. En estos últimos, incluso, la piedra ha dejado paso a los letreros luminosos, la imagen a la escritura, para marcar la hora nocturna, identifican alguna casa comercial, las bondades de productos importados de otras latitudes o informan de algún acontecimiento importante.

La veneración e identificación de la tradición andina con las cumbres, aunque reelaborada, sigue presente hasta hoy. El cerro Dragón de Iquique, una enorme duna de arena, es un símbolo de la ciudad: el equipo que la representa en el fútbol profesional es denominado como los "dragones" celestes. Anca tiene en su "histórico" morro, un peñón de piedra, no sólo al símbolo de la ciudad, sino también un elemento que marca su reciente nacionalidad: en su falda un neogeoglifo con feroces corvos, como significantes del ejército chileno, se la señalan diariamente a sus habitantes y a los visitantes de los países vecinos.

\section{Identidades emergentes}

\section{Un componente de marginalidad}

En estos tiempos, en que se acentúa la desigual distribución de los ingresos y la pobreza tiende a hacerse más dura, el componente cultural de la marginalidad urbana regional ha sido muy descuidado o simplemente no tratado por los estudios sociales en la región. A simple vista, aunque se puede plantear la subsistencia de ciertos elementos asociados al concepto de solidaridad vecinal, también han aparecido otros más preocupantes que tienen que ver, principalmente, con un aumento del consumo suntuario y, entre los segmentos jóvenes, de la drogadicción.

La solidaridad como mecanismo de respuesta cultural popular todavía es visible en las redes de ayuda mutua entre vecinos frente a situaciones problema (cuidado de menores, protección de desvalidos, etc.) o desgracias (enfermedad, muerte, etc.), en empresas y organización colectivas (comités de allegados, sin techo, pavimentación, etc.), en prácticas deportivas (clubes) y de entretención (juegos infantiles, multicanchas). Atentan contra la integración vecinal los desplazamientos de población que han afectado a los barrios tradicionales, el recambio generacional y la aparición de patologías sociales más serias, como el consumo de pasta base y sus secuelas (robos, asaltos, destrucción familiar, etc.) entre los más jóvenes.

La oferta de la Zofri ha penetrado fuertemente en los hogares de la región. Es común ver casas a punto de derrumbarse, pero apertrechadas de electrodomésticos, radios y equipos, videograbadores y grandes televisores. Los autos abandonados en las puertas de las viviendas en los sectores populares forman parte ya del paisaje urbano. El consumo suntuario, especialmente vía crédito, parece haber escapado de los márgenes de la racionalidad del gasto economicista y vaga por límites culturales que han sido poco o nulamente prospectados por la investigación social.

La drogadicción entre los segmentos jóvenes de los sectores populares de Iquique y Arica es bastante fuerte. El consumo de pasta base ha originado no sólo patologías sociales clásicas en la adicción a drogas duras (robos, asaltos, crímenes), sino también desórdenes culturales que afectan a instituciones clásicas del mundo marginal: la solidaridad barrial y el orden institucional familiar. La conducta de los "moneros" plantea una subversión de límites culturales tradicionales en el mundo popular. Ya no se delinque fuera sino dentro del barrio o la familia: se asalta al vecino, se roba y maltrata a los padres. La cultura de la marginalidad ha tenido que integrar a la fuerza a estos nuevos personajes, sus vestimentas y jerga, su convivencia con la "pálida".

\section{Indígenas en la ciudad}

En un proceso que se inicia de manera más masiva en los años sesenta, la mayor parte de la población aymara chilena reside actualmente en las zonas urbanas de la región. Se calcula que existen más de 30.000 personas de origen aymara (chilenos $\mathrm{y}$, en menor medida, bolivianos) residiendo en las ciudades de Iquique y, principalmente, Arica. Esta situación es importante en dos sentidos. Primero, en lo que significa para los propios aymaras, ya que su problemática cultural no puede seguir siendo pensada solamente desde una óptica rural o campesina. Segundo, en lo que los migrantes representan dentro de los dos centros urbanos regionales, ya que aunque sólo representarían entre un 10 y un $15 \%$ de la población total de los mismos, los migrantes aymaras han constituido mayoría en ciertos espacios residenciales sociales y económicos de la ciudad.

Actualmente constituyen un elemento visible en las ciudades porque han copado o son mayoría en ciertos barrios. Ocurre así en Arica en los sesenta y comienzos de los setenta, cuando existieron espacios 
abiertos a la colonización urbana (tomas de terreno y operaciones sitio) $\mathrm{y}$, posteriormente, cuando ya no hay sitio para ocupar libremente, en esta misma ciudad y en Iquique, en las poblaciones de subsidio. En su convivencia con los otros pobres de la ciudad, han traspasado cuestiones como el consumo de la carne de camélido. En barrios donde son mayoría, han copado colegios y liceos (especialmente los politécnicos).

35 En otra parte (H. González, 1997a) hemos señalado la importancia de las ocupaciones por cuenta propia o "independientes" en la ciudad como mecanismos de reproducción cultural: se puede abandonar la actividad de forma temporal o dejarla a cargo de otros mientras se asiste a la fiesta del poblado en el interior o se viaja a ver las pertenencias rurales (animales o cultivos).

36 A. Díaz (1997), quien junto a otros estudiantes de Historia y Geografía de la Universidad de Tarapacá realizó un sondeo de radioescuchas de este tipo de música en la ciudad de Arica, distingue acertadamente entre música chicha y cumbia andina por la estructura de las melodías y la preponderancia de ciertos instrumentos. En la primera, que habría popularizado el mítico conjunto de los "Shapis" entre los migrantes andinos de los pueblos jóvenes de Lima, la melodía se intervala con constantes punteos de guitarra eléctrica, que acompañan incluso al vocalista; en la segunda, que tendría una mayor tradición en la zona andina chilena, la guitarra es reemplazada en importancia por el teclado (órgano electrónico).

37 Los tambos son una manifestación nortina de la conocidad peña folclórica. Sitios de canto y baile, albergaban a solistas y conjuntos universitarios de "proyección" folclórica (representaciones de cuadros costumbristas aymaras o de la pampa); como fenómenos masivos se terminaron durante el gobierno militar (cf. B. Guerrero, 1996). En Iquique, se denomina actualmente "tambos" o "tropitambos" (por la música tropical andina) a los bailables a los que asisten migrantes aymaras en la ciudad.

38 Nótese la influencia del idioma inglés o de modernismos en los nombres de los conjuntos, fenómeno que es también extensible a bandas similares bolivianas (Odisea 2000, Clímax, etc.) o peruanas (Bio-chips, Super Genéticos, etc.). Este fenómeno ha llegado también a los nombres propios de las nuevas generaciones aymara, con la aparición de John (Yon o Jonny), Michael (Mickel, Miky o Maykel), etc.
Dentro de la ciudad desempeñan de preferencia ocupaciones por cuenta propia y el manejo económico sigue siendo familiar, de acuerdo al modelo campesino del que provienen. De esta manera han copado también ciertos sectores económicos de las ciudades, siendo los principales los del comercio detallista y carnicerías en barrios populares, comercio ambulante $\mathrm{y}$, principalmente, los terminales y mercadillos agropecuarios. También conectan vía comercio y transporte el sector rural con el urbano ${ }^{35}$.

La música tropical andina en sus dos versiones (chicha y cumbia) ${ }^{36}$, presente en las radios de los terminales agrícolas, que escuchan en los taxis colectivos que manejan por la ciudad y en los bailables a los que acuden los fines de semana (en quintas de recreo, en tambos o "tropitambos") $)^{37}$, se ha extendido también hacia los sectores populares. De esta manera, son famosas las bandas compuestas por jóvenes migrantes, que han pasado de la caña y el bronce a los instrumentos electrónicos. Conjuntos locales como Fusión Tropical, Gran Amanecer Internacional o Amanecer de Talo Baltazar de Arica; y Genitman's o Tropical Sound de Iquique, actualmente son contratados en un radio que va desde Arica hasta la IV Región ${ }^{38}$.

\section{La minería del cobre}

En el sector cordillerano de la región se están desarrollando una serie de medianos y grandes proyectos mineros. Descontando su aporte al desarrollo económico, en términos de inversión y empleo, todavía no se ha tomado debida cuenta de su incidencia a nivel cultural: de las diferencias entre este tipo de minería y la experiencia salitrera, de los sistemas de trabajo por turnos y de la segregación social por residencia y consumo que provocan los mayores ingresos.

La minería moderna se mueve en un tipo de organización laboral y tiene desarrollos tecnológicos muy diferentes a los imperantes en la producción salitrera, sobre la que se funda la experiencia histórica que los habitantes de la región tienen con el mundo minero. Esta no es una cuestión que afecta sólo a los mismos trabajadores, sino también a la percepción ciudadana del fenómeno minero: la canícula de la pampa es reemplazada por el soroche y el frío de la "puna"; la oficina-pueblo, abierta, desordenada y bullente, se cambia por el campamento cerrado, aséptico y ordenado; el grupo familiar por el hombre solo; la fuerza humana o animal por la máquina, etc.

Los sistemas de trabajo por turnos (cuatro o siete 
días en la mina por los mismos de descanso en la ciudad o muchos más días de labor por menos de reposo en el caso de los empleados con empresas contratistas), producen efectos sociales y culturales todavía no prospectados por la investigación. Sin embargo, fenómenos como el de esposas a cargo temporalmente de los hogares o de aquellos englobados en el concepto de la "bajada del minero", con hombres que buscan entretención en centros nocturnos o en shoperías del puerto como una forma de ahogar o desahogar el cansancio y el rigor del trabajo corrido en un medio inhóspito, son visibles por la comunidad.

Los trabajadores de las empresas mineras perciben, aparte de otros beneficios, salarios comparativamente más altos que el común. Estas diferencias en ingresos y regalías se traducen en mayores niveles de consumo suntuario, en el acceso a mejor educación para los hijos y salud para el grupo familiar, en una segregación espacial de sus modernas villas, custodiadas por guardias, con el resto de la población. Estos y otros aspectos están provocando una separación cultural con la comunidad local. Se trata de un fenómeno nuevo y diferente, que no se compara con la relación sostenida anteriormente con el trabajador del salitre y su cultura.

\section{El surf o la cultura de la playa}

Entre los habitantes de la costa de la I Región existe

39 Los logros y los héroes de estas ramas deportivas en Iquique han sitio reseñadas por B. Guerrero (1992). No existe un texto semejante para Arica, sin embargo, a través de los medios de comunicación formales o informales, la ciudad conoce bastante de sus éxitos en natación, waterpolo y saltos ornamentales.

40 Este fenómeno ha sitio, sin duda, reforzado con las irnágenes de una telenovela nacional ambientada en

las playas de Iquique y en el inundo del surf.

41 N. García Canclini (1990). El concepto de reterritorialización, "de relocalización territoriales relativas, parciales, de las viejas y nuevas producciones simbólicas", planteado por este mismo autor (op. cit: 288), también puede señalarse a nivel regional. Como ejemplo, puede citarse el caso de los aymara, tanto en el movimiento de elementos culturales desde las comunidades a la ciudad que realizan los migrantes, como en la influencia cte los mismos en sus localidades rurales de origen donde trasladan paisajes y costumbres urbanas. una fuerte relación con el mar. Aparte de la antigua importancia del sector de pescadores y mariscadores artesanales, con sus caletas, barrios, festividades y, posteriormente, de la pesca industrial, los paseos familiares a la playa, los deportes acuáticos (natación, waterpolo, caza submarina) ${ }^{39}$, la recolección y pesca de orilla para "llevar" algo a la casa o compartir en la misma playa con el grupo de amigos o la familia, son prácticas culturales bastante arraigadas entre la población.

Actualmente ha aparecido un nuevo fenómeno que parece inscribirse dentro de esta misma relación cultural. Las playas de Iquique y Arica, tanto en invierno como en verano, se inundan de jóvenes que "corren" las olas en sus tablas. Se podría pensar en ellos como una continuidad de esa antigua vinculación con el mar que arranca, incluso, desde la prehistoria. Sin embargo, ya no se trata de cazadoresrecolectores marinos, la vinculación de estos jóvenes con el mar ya no es "productiva", sino "lúdica".

Con su atuendo típico, su pelo, su vestimenta, su forma de vida y lenguaje parecen más bien una imitación o un remedo local de aquellos surfistas de las playas californianas y hawaianas. Contra lo que pudiera pensarse por lo costoso de sus implementos, ellos provienen de todos los estratos socio-económicos, aunque existen ciertas diferencias en el uso de ciertas playas o segregaciones grupales por sector social de proveniencia. La masificación de este práctica y su intrusión en todas las capas sociales ${ }^{40}$, dan cuenta de la emergencia de un nuevo fenómeno cultural juvenil.

\section{Desterritorialización de las identidades: la globalización}

\section{Apertura mercantil y cultura}

La pérdida de la relación natural de la cultura con sus territorios geográficos y sociales es un fenómeno que se ve favorecido por la modernidad, por la globalización de las economías y, especialmente, por el avance de las redes de comunicación mundial ${ }^{41}$. La región no escapa o, más bien, no puede escapar a este proceso. En el caso de la apertura económica, no obstante, se pueden apreciar fenómenos y cuestionamientos culturales diferentes según se trate de Arica o Iquique. Aunque, sin duda, pueden existen otras vertientes de descripción y análisis para este tema, nos ha parecido interesante resaltar la distinta relación que ambas ciudades parecen tener con la globalización económica. 


\section{El cosmopolitismo en lquique}

La Zona Franca de lquique y sus productos conectan la economía regional con los países industrializados del Asia-Pacífico y con los mercados de Perú, Bolivia, Paraguay y Argentina. Pero no se trata sólo de un fenómeno económico, detrás o junto a las mercancías llegaron comerciantes y clientes con culturas extranjeras. De esta manera, es común ver en esta ciudad a importadores coreanos, hindúes, libaneses o de otra latitud, a compradores de Bolivia, Perú, Paraguay o Argentina, entremezclados con la población local y viajeros de otros puntos del país que llegan también atraídos por la ZOFRI.

La mezcla de tipos físicos y culturales, la convivencia de la peculiar arquitectura de madera del pasado salitrero con la de los modernos edificios, la coexistencia de la particular cultura local con la de los inmigrantes, le imprimen a la ciudad un aire cosmopolita. A pesar del fuerte chauvinismo que les caracteriza, los "tradicionales" iquiqueños se han mostrado abiertos para acoger a los nuevos vecinos y su diversidad ${ }^{42}$. En este caso la apertura cultural parece acompañar a la económica.

La reacción cultural de esta ciudad tiene raíces históricas. Como se señaló más arriba, el periodo salitrero fue también un fenómeno cosmopolita. La pampa e Iquique se poblaron de manera masiva sólo a partir del último cuarto del siglo pasado, antes la primera estaba prácticamente vacía y la segunda era nada más que una caleta. Atraídos por el esplendor económico llegaron inmigrantes de otras partes del país y del extranjero. La pampa y el puerto se constituyeron también a partir de la síntesis cultural. La ZOFRI es un fenómeno económico nuevo, pero puede fluir por el carril de una vieja y fundarte experiencia de cosmopolitismo cultural.

\section{El estatismo y nacionalismo en Arica}

Anca vive un largo periodo de ostracismo desde finales del S. XVII, cuando declina el mineral de Potosí, del cual era el puerto de entrada y salida, y

42 La primera versión del Del chumbeque a la Zofri de

B. Guerrero (1990), es en gran medida una reacción a la amenaza que el fenómeno de la zona franca supondría para la identidad iquiqueña "tradicional". mediados del S. XX, cuando se activa económica y poblacionalmente producto de una serie de medidas estatales de excepción. Primero se la declara Puerto Libre, luego se crea una Junta de Adelanto que invierte los impuestos recaudados en la misma zona y posteriormente se implementa un dinámico Polo Industrial. Este periodo de auge de la ciudad durará hasta mediados de los años setenta, cuando la política neoliberal del gobierno militar elimina las medidas especiales de subsidio económico y se abren las barreras arancelarias.

En los últimos veinte años la ciudad ha vivido una fuerte contracción económica. Los ariqueños se sienten actualmente meros observadores del desarrollo del país y, especialmente, de Iquique, su eterna rival. La respuesta cultural es hasta ahora nostálgica del periodo de auge. Se evoca cotidianamente el movimiento, las inversiones y el adelanto vivido o conseguido en el pasado. Se demandan también medidas económicas del ayer: subsidio estatal o políticas de excepción. Para los ariqueños la reactivación económica de su ciudad pasa por una decidida intervención del Estado, precisamente cuando éste jibariza su accionar a nivel nacional y mundial. En este caso, al apabullarte tren de la apertura económica mercantil se le ofrece un riel extraño: una cultura de la nostalgia estatista.

En un contexto parecido, se espera que la globalización de las economías producirá un avance en la integración económica de Chile, Perú y Bolivia, tanto entre ellos como con respecto a los mercados del área Pacífico y Atlántico. Actualmente, por ejemplo, el tema de los corredores bioceánicos es una necesidad sentida y se dan pasos hacia su implementación. Sin embargo, existen señales que los cambios culturales que implica la integración serán más lentos, ya que será necesario vencer las barreras y diferencias históricas que perduran entre estos países desde la Guerra del Pacífico. Este fenómeno es especialmente visible en Arica.

Aparte de su situación de zona de ocupación relativamente reciente, su condición fronteriza hace de Arica un lugar donde se exacerba más el nacionalismo. Esta situación determina una actitud de rechazo cultural a los vecinos. Pese a que es importante la presencia de peruanos y bolivianos en ciertos espacios económicos, hasta ahora pasa como si esta ciudad sólo se reprodujera por el esfuerzo de sus puros ciudadanos chilenos. Se hace invisible así la relevancia de empresas bolivianas en las actividades portuarias, en el transporte, las migraciones temporales de indocumentados a los valles agrícolas, la 
presencia de pequeños agricultores y comerciantes en los terminales agropecuarios, etc. Ocurre lo mismo con el comercio hacia y desde Tacna, tanto de empresarios como de vendedores ambulantes, del inundo de las empleadas domésticas, etc. Estos antecedentes permiten pronosticar que el nacionalismo, que es una construcción cultural, será una fuerte barrera a la integración económica.

\section{La simultaneidad de la noticia y la cultura}

Si bien la influencia cultural a través de los medios de comunicación tiene ya cierta antigüedad, actualmente sorprende su rapidez de propagación. Como en otras latitudes, los adelantos en los sistemas de transmisión posicionan y relacionan simultáneamente a los habitantes de la región con las noticias y la cultura de otros puntos del orbe. Este fenómeno no tiene sólo consecuencias en términos de la asimilación de elementos culturales provenientes de otros territorios económicos y sociales, sino también respecto de un cambio en las modalidades de internalización de la cultura.

Es sorprendente la cantidad de hogares conectados a la televisión por cable. Esta situación tiene efectos económicos y culturales. Por un lado, incluso los sectores populares han incorporado la renta mensual de este servicio dentro de su canasta básica de consumo cultural ${ }^{43}$. Por otro, se producen una serie de modificaciones en los patrones culturales, que afectan el habla, la cocina, la música, la moda, etc. De esta manera se han importado palabras caribeñas y anglicismos, comida mexicana, tragos brasileños, peinados y vestimenta, conductas, que conviven con las prácticas nativas anteriores.

Actualmente la oferta y el consumo de bienes culturales pasa más por registros audiovisuales, se vive mas en un mundo de imágenes que de texto. De esta manera, en términos de formación de patrones culturales, para un niño un programa de dibujos animados japonés o americano es más importante que la lectura de un cuento maravilloso, para un joven un video de MTV es más relevante que un libro de poesía, la telenovela brasileña o mexicana ha reemplazado a la antigua novela amorosa por entre-

43 Incluso, cuando no se puede asumir el gasto o no se les ha cortado el servicio, queda la alternativa de "colgase" del vecino. gas, etc. Estos ejemplos señalan un cambio en los mecanismos de internalización de la cultura, un fenómeno que no ha sido para nada investigado en la región.

\section{A modo de conclusión: Algunos apuntes sobre identidades perdidas}

El tema de las identidades culturales perdidas se puede enfocar también desde la perspectiva de los grupos sociales o de ciertos componentes importantes para el imaginario cultural regional. Existen grupos que han desaparecido, están en vías de serlo o pierden cada vez más importancia dentro del mosaico social regional. No obstante, como se ha visto más arriba, todavía se pueden detectar elementos de su cultura que siguen influyendo en la región. Por otro lado, también es posible observar que varios e importantes componentes culturales de los grupos todavía vigentes se han perdido, sufrido deterioro o transformado

Todavía es posible ver a descendientes de los grupos de negros esclavos que trabajaron en las haciendas de oasis o valles bajos durante la colonia. Su presencia se observa sobre todo en ciertos sectores del valle de Azapa. Sin embargo, esta constatación física no tiene correlato en el plano de la cultura, ya que se sabe casi nada de su influencia cultural. En este caso se puede hablar en propiedad de pérdida, tanto social como cultural, ya que son poco numerosos y se encuentran culturalmente muy asimilados.

Lo mismo ocurre con la colonia china descendiente de los esclavos que llegaron a trabajar en las guaneras o, posteriormente, como comerciantes en el periodo salitrero. Sin embargo, en este caso todavía se puede observar alguna influencia. La imagen del almacenero, del "chino de la esquina" todavía sigue vigente en el imaginario cultural de los barrios populares de las ciudades de la costa. En el cotidiano, la comida china o la influencia de sus modos de preparación y aliños forma parte de la cultura regional. Pero, gran parte de su cultura ha desaparecido, sus curanderos, sus fumaderos de opio e, incluso, sus centros y clubes sociales de reunión ya no forman parte del paisaje cultural de la región.

Aunque existen algunos elementos de su cultura que siguen siendo muy importantes en los sistemas de identidad de la región, el pampino ha desaparecido como grupo social y económico y, junto a ellos gran parte de su cultura. De todas maneras, todavía se esfuerzan por conservar algunos centros sociales 
(como el activo Nebraska en Iquique) y celebran el día de la pampa en la oficina Santiago Humberstone. Varios de ellos también están ligados a iniciativas de revalorización de la cultura pampina en la ciudad, que llevó a cabo el Taller de Estudios Regionales y todavía continúan algunos de sus ex-integrantes, que se ha traducido en la publicación de textos, fotografías, literatura, etc.

Otro grupo afectado por procesos de pérdida y deterioro cultural es del sector pesquero artesanal local. Los continuadores de la antigua tradición cazadora-recolectora de los changos del litoral, hoy prácticamente han desaparecido o han sido reemplazados por inmigrantes del norte chico y el sur, que se han establecido fuera de las ciudades, en Camarones y en ciertas playas entre Iquique y El Loa. Las caletas antiguas de los puertos, alrededor de las cuales formaron sus barrios los pescadores, han disminuido y se han reagrupado. Presionados por la renovación urbana, muchos de ellos se han trasladado -o han sido trasladados- de sus antiguos sectores residenciales a otras áreas de la ciudad.

Por su importancia, como grupo social y por los componentes que todavía aportan a los sistemas tradicionales de identidad cultural regional, los pescadores artesanales quizás debieran incluirse dentro del capítulo dedicado en este trabajo a los elementos de continuidad. Se han incluido en este apartado pues nos parece que la dispersión residencial a la que han sido sometidos, que ha desintegrado la cohesión social que les proporcionaban sus barrios, la llegada de inmigrantes $\mathrm{y}$, principalmente, la discontinuidad del oficio por parte de las generaciones de reemplazo, que prefieren emplearse en el sector pesquero industrial (como "tripulantes"), están produciendo un evidente proceso de pérdida cultural o, al menos, que la pesca artesanal como fenómeno cultural ya no es la misma.

Los aymaras, aunque se mantienen totalmente vigentes como grupo cultural, incluso en sitios tan adversos como las ciudades costeras, también han soportado fuertes procesos de deterioro y pérdida de muchos de sus componentes culturales tradicionales. Han desaparecido manufacturas artesanales como la alfarería y la platería, han cambiado su vestimenta y hábitos alimenticios, han reemplazado las caravanas de llamas y las mulas por vehículos motorizados, han incorporado la escuela formal, con todos sus contenidos desarraigantes, etc. De todas maneras, quizás el sector de su cultura más fuertemente afectado sea el religioso, especialmente cuando se convierten a sectas pentecostales, con la desaparición de mitos, festividades y la reformulación de muchas de sus creencias.
44 Existen diagnósticos sobre el sector pesquero artesanal para las áreas de Iquique (R. Ávila et al., 1989) y Arica (J. Toro et al., 1990). Existe también un diccionario de voces de la pesca artesanal (J. Van Kessel, 1986). El texto de L. Núñez (1996), aunque con otros fines, en su recreación de la vida cotidiana del barrio El Mono de Iquique contiene también bastante información sobre la cultura de estos pescadores.

45 Algunos autores han asimilado la conversión al pentecostalismo con la desaparición del ser aymara tradicional (cf. J. Van Kessel, 1985; J. Van Kessel y B. Guerrero (1987); y B. Guerrero (1980; 1981; 1984). 


\section{BIBLIOGRAFIA}

ADVIS, Patricio; Ique-Ique de los pescadores. La caleta prehis1994 pánica (1535). Tarapacá: una aventura en el tiempo, pg. 58-63, Taller de Estudios Regionales, Iquique.

ARRATIA, María; Problemas conceptuales de la antropología y 1990 sus implicancias: crítica al concepto de matriz cultural. Diálogo Andino 11/12: 3346, Universidad de Tarapacá, Arica.

AVILA Roberto. Jorge TORO y Juan PODESTÁ; Diagnóstico 1989 del sub-sector pesquero artesanal de la provincia de Iquique. Cuadernos de Estudios Regionales, $\mathrm{N}^{\circ}$ I, CEPAAT, Iquique.

BERENGUER, José y Percy DAUELSBERG; El Norte Grande 1989 en la órbita de Tiwanaku (400 a 1.200 d.C.). Culturas de Chile. Prehistoria, pg. 129-180, Ed. Andrés Bello, Santiago.

BERMUDEZ, Oscar; Historia del salitre desde sus orígenes 1963 hasta la Guerra del Pacífico, Ediciones de la Universidad de Chile. Santiago.

$1984 \quad$ Historia del salitre desde la Guerra del Pacífico hasta la Revolución de 1891, Ediciones Pampa Desnuda. Santiago.

1987 El oasis de Pica y sus nexos regionales, Ediciones Universidad de Tarapacá, Arica.

BLAKEMORE, Harold; Gobierno chileno y salitre inglés. 18861977 1896: Balmaceda y North. Ed. Andrés Be1lo, Santiago.

BRIONES, Luis; Fundamentos metodológicos para el relevamien1984 to de los geoglifos del norte de Chile. Chungará 12: 41-56, Universidad de Tara-pacá, Arica.

BRIONES, Luis y Juan CHACAMA; Arte rupestre de Ariquilda: 1987 análisis descriptivo de un sitio con geoglifos y su vinculación con la prehistoria regional. Chungará 18: 67-90, Universidad de Tarapacá, Arica.

CARRASCO, Ana María; Participación femenina en el mercado 1995 de trabajo de la ciudad de Arica. Temas Regionales 2-2: 47-56, Ed. Corporación Norte Grande, Arica.

CASTRO. Luis; Las mujeres y su realidad en la industria 1994 salitrera. Tarapacá: una aventura en el tiempo, pg. 19-24, Ediciones Especiales Camanchaca, Taller de Estudios Regionales. Iquique.

DAGNINO, Vicente; El correjimiento de Arica. 1535-1784, 1909 Imprenta la Epoca, Arica.

DEVES, Eduardo; La cultura obrera ilustrada en tiempos del Cen1994 tenario. Tarapacá: una aventura en el tiempo, pg. 75-82, Ediciones especiales Camanchaca, Taller de Estudios Regionales, Iquique.

DIAZ, Alberto; "Sigue la cumbia". Percepción de la cumbia andi1997 na en la ciudad de Arica: un ejercicio. Revista Percepción 1:24-38, Taller de investigaciones culturales Tincu, Dirección de Asuntos Estudiantiles, Universidad de Tarapacá, Arica.
GARCIA, José Javier; Los bailes religiosos del norte de Chile. 1989 Los danzantes de la Virgen, Publicaciones Teológicas, Santiago.

GARCIA CANCLINI, Néstor; Culturas híbridas. Estrategias 1990 para entrar y salir de la modernidad. Editorial Grijalbo, México.

GAVILÁN, Vivian; Una aproximación a las relaciones de género 1995 entre los aymara del norte de Chile. Temas Regionales 2-2: 21-34, Ed. Corporación Norte Grande, Arica.

GONZALEZ, Héctor; Acerca de la constitución de la condición 1995 de Mujer Jefa de Hogar en sectores pobres de la ciudad de Arica. Temas Regionales2-2:57-78, Ed. Corporación Norte Grande, Arica.

1996 Características de hi migración campociudad entre los aymaras del norte de Chile, Corporación Norte Grande, Serie Documentos de Trabajo, Arica.

1997 Economía y uso del espacio en la sociedad aymara actual. Actas Segundo Congreso Chileno de Antropología, pg. 567-579, Santiago.

1997a La inserción económica de los migrantes aymara en la ciudad. El trabajo como empresa familiar y la reproducción cultural. Actas Segundo Congreso Chileno de Antropología, pg. 315-324, Santiago.

GONZALEZ, Héctor y Vivian CAVILAN; Cultura e 1991 identidad étnica entre los aymaras chilenos. Chungará 24-25:145-158, Universidad de Tarapacá, Arica.

GONZALEZ, Héctor y Hans GUNDERMANN; 1996 Organizaciones aimaras, identidad étnica e integración. La integración surandina cinco siglos después, pg. 395-416, Ed. Centro Bartolomé Las Casas, Cuzco, Perú.

GONZALEZ, Sergio; El Aymara de la provincia de 1990 Iquique-Chile y la educación nacional. Cuadernos de educación intercultural 1 : 1-68, Taller de Estudios Regionales, Iquique.

1990 La identidad regional en Tarapacá: El caso salitrero a modo de ejemplo. Diálogo Andino. 9: 73-82, Universidad de Tarapacá, Arica.

1991 Hombres y mujeres de la pampa: Tarapacá en el ciclo del salitre, Ediciones especiales Camanchaca, Taller de Estudios Regionales, Iquique.

1995 El poder del símbolo en la chilenización de Tarapacá: violencia y nacionalismo entre 1907 y 1950 . Revista de Ciencias Sociales 5: 29-39, Universidad Arturo Prat, Iquique.

1995ª Elsa Sánchez: testimonio inconcluso de una militante comunista del período heroico salitrero en Tarapacá. Temas Regionales 2-2: 1-10, Ed. Corporación Norte Grande, Arica. 

Iquique.

1996 Civilizando al yatiri: la labor docente de los maestros normalistas en el mundo andino de la provincia de Iquique antes de la reforma educacional de 1965. Revista de Ciencias Sociales 6:3-58, Universidad Arturo Prat, Iquique.

Maestras chilenizadoras y peruanistas. Boletín de Educación, Depto. Estudios Humanísticos, UniversidadCatólicadel Norte, Antofagasta (en prensa).

1997a Tarapacá, Dios cautivo. Valles. Revista de Estudios Regionales 2: 111-120, Museo de La I.igua, La Ligua.

GONZALEZ, Sergio (compilador); Glosario de voces de la 1992 pampa. Tarapacá en el ciclo del salitre, Ediciones especiales Camanchaea, Taller de Estudios Regionales, Iquique.

GUERRERO, Bernardo; La estructura ideológica del movimiento pentecostal, Cuadernos de Investigación Social 1:1-12. CIREN, Iquique.

1981 La violencia pentecostal en el altiplano chileno. Cuadernos de Investigación Social, $\mathrm{N}^{\circ} 4$, CIREN, Iquique.

1984 Movimiento pentecostal, corrientes modernistas y sociedad aymara. Cuadernos de Investigación Social, $\mathrm{N}^{\circ} 8, \mathrm{CIREN}$, Iquique.

1992 El libro de los campeones: deporte e identidad cultural en Iquique. Ediciones El Jote Errante, Iquique.

1995 "La Diosa Verdad": Belén de Sárraga y anticlericalismo en Iquique. Temas Regionales 2-2: 11-18, Ed. Corporación Norte Grande, Arica.

1996 Del chumbeque a la Zofri. La identidad cultural de los iquiqueños. Ediciones El Jote Errante. Iquique.

GUNDERMANN. Hans; ¿Cuántos hablan en Chile el aynlara?. Revista de Lingüística Teórica y Aplicada. 125-139, Universidad de. Concepción, Concepción.

GUNDERMANN, Hans y Héctor GONZALEZ; Cultura Ayma1989 ra, Ministerio ele Educación, Santiago.

HENRIQUEZ, Patricia; ¿Por qué bailando? Estudio de los 1994 bailes religiosos del Norte Grande de Chile. Prntext, Santiago.

HIDALGO, Jorge; Indian society in Arica, Tarapacá and Atacama, $1986 \quad \mathbf{1 7 5 0 - 1 7 9 3}$, and its response to the rebellion of Tupac Amaru. Tesis Doctoral, University of London, Londres, Inglaterra.

LARRAIN, Jorge; Modernidad, razón e identidad en Amé1995 rica Latina, Editorial Andrés Bello, Santiago.

LLAGOSTERA, Agustín; Caza y pesca marítima (9.000 a.C 1.000

1989 a.C.). Culturas de Chile. Prehistoria, pg. 57-80, Ed. Andrés Bello, Santiago

MONTECINO, Sonia; Madres y huachos. Alegorías del mestiza1991 je chileno, Editorial Cuarto Propio-Cedem, Santiago.

MORANDE, Pedro; Cultura y modernización en América La1984 tina, Cuadernos del Instituto de- Sociología, Pontificia Universidad Católica de Chile, Santiago.
MOTSNY, Grete y Hans NIEMEYER; Arte Rupestre Chileno. 1983 Serie Patrimonio Cultural Chileno, Ministerio de Educación, Santiago.

MUÑOZ, Iván; El período formativo en el Norte Grande 1989 (1.000 a.C. a 500 d.C.). Culturasde Chile. Prehistoria, pg. 107-128, Ed. Andrés Bello, Santiago.

NIEMEYER, Hans; Las pinturas rupestres de la sierra de Ari1972 ca, Editorial Jerónimo de Vivar, Santiago.

NUÑEZ, Lautaro; La agricultura prehistórica en los andes me1974 ridionales, Ed. Orbe, Santiago.

1975 Geoglifo y tráfico de caravanas en el desierto chileno. Homenaje al Dr. R.P. Gustavo Le Paige S.J., pg. 147-201, Universidad del Norte, Antofagasta.

1985 Geoglifo y tráfico en el desierto de Chile. Estudios de Arte Rupestre, pg. 243-264, Museo Chileno de Arte Precolombino, Santiago.

1989 Los primeros pobladores (20.000? a 9.000 a.C.). Culturas de Chile. Prehistoria, pg. 13-32, Ed. Andrés Bello. Santiago.

1989a Hacia la producción de alimentos y la vida sedentaria. Culturas de Chile. Prehistoria, pg. 81-106, Ed. Andrés Bello. Santiago.

1989 $\quad$ La Tirana del Tamarugal. Del misterio al sacramento. Universidad del Norte, Antofagasta.

1996 Avísale Freddy. Freddy Taberna Gallegos: desde El Morro a la leyenda iquiqueña, Ediciones Iquiquetias. Antofagasta.

PA L A C I O S. Raúl; La chilenización ele Tacna y Arica 1883-1929, 1974 Ed. Arica S.A.. Lima. Perú.

PINTO, Jorge; Ser hombre en el Norte Chico: El testimonio de un 1996 historiador. Diálogos sobre el género masculino en Chile, Programa Interdisciplinario de Estudios de Género, Varios Autores, Bravo y Allende Editores, Santiago, Chile.

RIVERA, Hernán; La reina Isabel cantaba rancheras, Editorial $1994 \quad$ Planeta, Santiago.

RODRIGUEZ, Gustavo; Conciencia de clase y cultura mine1987 ra (1865-1923), Cochabamba. Bolivia.

SABELLA, Andrés; Norte Grande. Novela del Salitre, Editorial 1959 Orbe. Santiago.

SANTORO, Calogero; Antiguos cazadores de la puna (9.000 a $1989 \quad 6.000$ a.C.). Culluras ele Chile. Prehisto ria, pg. 33-56. Ed. Andrés Bello, Santiago.

SCHIAPACASSE, Virgilio, Victoria CASTRO y Hans NIE1989 MAYER; Los desarrollos regionales en el Norte Grande (1.000 a 1.400 d.C.). Culturas de Chile. Prehistoria. pg. 181220, Ed. Andrés Bello, Santiago.

TABILO, Kapris; Hacia la construcción del género femenino y 1995 masculino en relatos ele tradición oral andina del norte de Chile, Temas Regionales 22: 35-46, Ed. Corporación Norte Grande, Arica.

TABILO Kapris, Franco VENEGAS y Héctor GONZÁLEZ; Las 1995 agrupaciones ele residentes aymara urbanos en el norte de Chile: Adaptación a la ciudad y vínculos con las comunidades de origen, Corporación Norte Grande, Serie Documentos de Trabajo, Arica, Chile. 
TORO Jorge, Roberto ÁVILA y María PIZARRO; Perfil econó1990 mico y social del sub-sector pesquero artesanal de la provincia de Arica. Cuaderno de Estudios Regionales, $\mathrm{N}^{\circ} 3$, CEPAAT, Iquique.

TRELLEZ, Efraín; Lucas Martínez Vegazo: Funcionamiento 1982 de una ecomienda peruana inicial, Pontificia Universidad Católica del Perú, Fondo Editorial, Lima. Perú.

URIBE, Juan; Fiesta de La Tirana de Tarapacá, Ediciones 1968 Universitarias de Valparaíso, Universidad Católica de Valparaíso, Valparaíso.

URZUA, Luis; Arica, Puerta Nueva. Historia y folklore. Ed. 1982 Andrés Bello, Santiago.

VAN KESSEL, Juan ; Los aymaras contemporánesos de Chile 1985 (1879-1985): su historia social. Cuadernos de Investigación Social, $N^{\circ} 16$, CIREN, Iquique.

1986 Diccionario de pesca artesanal del Norte Grande de Chile, Ed. Universidad Libre de Amsterdam y Centro de Investigaciones de la Realidad del Norte, Iquique.

1988 Lucero del desierto: mística popular y movimiento social, universidad Libre de Amsterdam-Centro de Investigación de la Realidad del Norte, Iquique.

1992 Arica y la peña sagrada, Ediciones el Jote Errante, Iquique.
1993 Holocausto al progreso, los aymarás de Tarapacá, Editorial Hisbol, La Paz, Bolivia.

VAN KESSEL, Juan y Bernardo GUERRERO; "Sanidad y 1987 salvación" en el altiplano chileno: del yatiri al pastor. Cuadernos de Investigación Social, $\mathrm{N}^{\circ} 21$, CIREN, Iquique.

VASQUEZ, Erie; Más allá del río, s/r, Arica.

$$
1990 \text { de una ecomiend }
$$

VASQUEZ, Juan (compilador); Tarapacá: una aventura en el 1996 tiempo, Ediciones espaciales Camanchaca, Taller de Estudios Regionales, Iquique.

VILLALOBOS, Sergio; La economía de un desierto. Tarapacá 1979 durante la colonia, Ediciones Nueva Universidad, Santiago.

WORMALD, Alfredo; Frontera Norte, Editorial Orbe, Santiago. 1969

1970 El mestizo en el departamento de Arica, Editorial Ráfaga, Santiago.

1972 Historias olvidadas del Norte Grande, Depto. de Historia y Geografía, Universidad del Norte, Arica. 
